\title{
An Evaluation of Banana Macropropagation Techniques for Producing Pig Fodder in Northern Thailand
}

\author{
Elizabeth Langford ${ }^{1}$, Patrick J Trail ${ }^{2}$, Abram J Bicksler ${ }^{2} \&$ Rick Burnette $^{1}$ \\ ${ }^{1}$ ECHO, Inc., N. Fort Myers, Florida, USA \\ ${ }^{2}$ ECHO Asia Regional Impact Center, Chiang Mai, Thailand \\ Correspondence: Patrick Trail, ECHO, Inc., Asia Regional Impact Center, Chiang Mai, Thailand. E-mail: \\ ptrail@echonet.org
}

Received: January 27, 2017 Accepted: February 23, $2017 \quad$ Online Published: February 28, 2017
$\begin{aligned} & \text { doi:10.5539/sar.v6n2p48 } \\ & \text { URL: https://doi.org/10.5539/sar.v6n2p48 }\end{aligned}$

\begin{abstract}
Smallholder farmers raising pigs in northern Thailand rely heavily on banana stalks as a fermented feed source, but struggle to reproduce banana plants fast enough to keep up with consumption. This study evaluated a variety of techniques for rapidly multiplying banana plants, using techniques appropriate and affordable to smallholder farmers in order to help meet this demand. Propagation techniques of Musa (ABB) cv. 'Kluai Nam Wa' were conducted in greenhouse and field experiments in both lowland and upland areas of Chiang Mai Province, Thailand. In greenhouse experiments, six treatments were conducted during the dry and rainy seasons, while five different treatments were compared in the field. Treatments used various methods of mechanical injury or application of benzyl aminopurine (BA) to induce plantlet differentiation. Number of plantlets to emerge, days to emergence, and circumference of plantlets were observed over a 90-day period. Results indicate that time of year plays an important role in the macropropagation of bananas, as significantly higher numbers of plantlets emerged during the rainy season. Plantlets emerged in 65 days, on average, during the dry season, but took only 54 days during the rainy season. During the rainy season, the presence of BA produced more plantlets than the other treatments, but during the dry season, there were no differences among treatments. Overall, the number of plantlets produced in all treatments evaluated was very low; however we believe this research is an important contribution to the literature and acknowledge that there exists significant opportunity to capitalize on the low-cost appropriate technology benefits that macropropagation of bananas can deliver to smallholder farmers.
\end{abstract}

Keywords: banana, macropropagation, benzyl aminopurine, apical dominance, northern Thailand

\section{Introduction}

Bananas play a pivotal role in the lives of people in northern Thailand, both as a consumed product and as an income generating product. In upland areas, bananas are primarily produced for the local market, but tend to be used for a wide range of applications, including their use as pig fodder. Banana stalks are typically chopped and ensiled as a stored feed source for pigs. However, due to inadequate supplies of affordable planting material, farmers must use suckers from their own stock for propagation. In order to propagate and produce enough bananas for household consumption, sale, and as a feed source for pigs, farmers are in need of techniques that allow for rapid and affordable multiplication of bananas at the household level.

Bananas are a crop of global significance, and typically grow best between latitudes of $20^{\circ} \mathrm{N}$ and $20^{\circ} \mathrm{S}$, where there are predominantly tropical conditions. For growth and flower production, optimal temperatures are between $22^{\circ} \mathrm{C}$ and $31^{\circ} \mathrm{C}$ with rainfall of $2000-2500 \mathrm{~mm}$, spread evenly throughout the year (Robinson \& Saúco, 2010). Although these are ideal conditions, bananas can also grow in the subtropics, between $20^{\circ}$ and $30^{\circ}$ north or south of the equator with fluctuating temperatures, and low, poorly distributed rainfall. Northern Thailand is just south of $20^{\circ} \mathrm{N}$ latitude, where the climate is on the border between tropical and subtropical. Not having the ideal conditions for growing bananas, and unable to afford irrigation systems, using appropriate cultivars with drought resistance has become crucial for farmers.

One particular cultivar that is important to the region is 'Kluai nam wa'. It is a cross between M. acuminata x M. balbisiana hybrids and classified as a triploid (ABB) due to the predominance of the M. balbisiana genes, contributing to characteristics such as high vigor and drought resistance, immunity to yellow Sigatoka 
(Mycosphaerella musicola) disease, and having starchy pulp (Simmonds, 1966). Drought tolerance, in particular, has enabled this cultivar to thrive in northern Thailand during the long dry season. However, due to the apical dominance of the mother plant, natural regeneration is very slow. In a stalk's lifetime of 12-14 months, it will only produce 5-20 suckers (Singh, Uma, Selvarajan, \& Karihaloo, 2011).

There are a number of different methods of macropropagation that have been utilized around the world for bananas. Many of these methods use some form of technique to break the apical dominance of the banana in order to promote axillary growth. Disrupting the apical meristem suppresses the production of auxin, thereby allowing the growth of the axillary buds (Arinaitwe, Rubaihayo, \& Magambo, 1999). Apical dominance from the banana mother stalk, while alive, influences control over suckers, regulating the number of sucker formation. Many macropropagation techniques have tended to focus on mechanical damage to the apical meristem or by the application of appropriate growth regulators.

One important class of growth regulators used for macropropagation is the cytokinins. Cytokinins are "substances which, in combination with auxin, stimulate cell division in plants and which interact with auxin in determining the direction that differentiation of cells takes" (Wareing \& Phillips, 1970). Many of these cytokinins are created synthetically, but some occur naturally. One source of naturally occurring cytokinins is the coconut, with research suggesting that there are cytokinins such as trans-zeatin-O-glucoside $\left(\mathrm{Cl}_{6} \mathrm{H}_{23} \mathrm{~N}_{5} \mathrm{O}_{6}\right)$ and dihydrozeatin-O-glucoside $\left(\mathrm{Cl}_{6} \mathrm{H}_{25} \mathrm{~N}_{5} \mathrm{O}_{6}\right)$ found in young, green coconuts (Yong, $\mathrm{Ge}, \mathrm{Ng}$, \& Tana, 2009). Other studies have found these cytokins in mature coconuts as well (Ge, Yong, Tana, Yang, \& Ong, 2004).

Previous research has been conducted using different mechanical and chemical methods to block or disrupt apical dominance. In Cameroon, researchers have experimented with a technique known as PIF (Plants Issus des Fragments de Tige), whereby plants are produced from stem fragments. PIF is a technique in which a crosswise incision is made through the apical meristem of a corm, 5 to $40 \mathrm{~cm}$ in height, in order to break apical dominance. After a period of drying, to further stress the corm and help induce lateral growth, the corm is placed in a moist bed of sawdust until plantlets emerge (Boss, 2008). Researchers in Honduras studied an in-field technique for banana multiplication whereby mature banana plants were bent over at the top, the leaves were removed, and a thin, flat stake was driven into the center of the pseudostem. Within four months, 10- 15 suckers were produced per plant (Price, 1999).

In Ghana, researchers have experimented with a rapid field multiplication (in situ) of plantain using benzyl aminopurine (BA) and coconut water injected into the base of young sword suckers, 25 to $45 \mathrm{~cm}$, and then sprouted in moist sawdust (Osei, 2004). Osei found comparable results for numbers of plantlets produced using either BA or coconut water. This technique resulted in an average of 10-15 plantlets produced from one corm in 18 weeks (Osei, 2004). Jafari, Othman, \& Khalid (2011) point out that cytokinin Plant Gowth Regulators (PGRs) such as benzyl aminopurine also play an important role in banana tissue culturing. They found that the addition of just $6 \mathrm{mg} / \mathrm{l}$ of BA increased the number of shoots formed (Jafari, Othman, \& Khalid, 2011).

Another commonly used technique is the split-corm method, in which a corm can be cut into 4 sections, dipped into fungicide, and placed into sawdust. This technique has resulted in four new plantlets from one corm (Dzomeku, Banful, Ankoma, Yeboah, \& Darkey, 2000). In Columbia, Dr. Manzur Macias experimented with a technique similar to the PIF technique but performed in the field (Marcias, 2001). With this technique, young suckers, cv. 'FHIA 20' plantain, were exposed, the pseudostem removed above the rhizome collar, and the apical meristem cut out. The remaining fragment was then cut with crosswise incisions, filled with BA and covered with compost.

While a variety of banana macropropagation techniques are known to exist, there are still many questions and challenges regarding the science and practicality of these various methods, especially regarding climatic conditions, the feasibility of properly suppressing the meristem, and premature rotting of corms (Njukwe, Ouma, van Asten, Muchunguzi, \& Amah, 2013). It is also evident that very little research has been undertaken on this subject in Asia, with the small-scale farmer relatively unaware that there are potential techniques for increasing the rate of propagation of their banana plants. The objectives of this study were to evaluate a variety of techniques for the macropropagation of Musa (ABB) cv. 'Kluai Nam Wa', in their ability to produce higher numbers of banana plantlets than are currently being achieved locally. Additionally, these techniques were evaluated based on their ability to produce plantlets in shorter periods of time, during different times of the year, and in ways that are appropriate and affordable to the small-scale farmers and pig producers of northern Thailand. 


\section{Method}

\subsection{Experimental Design}

Two independent experiments, a greenhouse study and a field experiment, were initiated in northern Thailand between 2007 and 2008 to evaluate multiple banana macropropagation techniques. Experiments were conducted at two different sites in Chiang Mai province, representing lowland and upland environments. The lowland greenhouse study was conducted at Chiang Mai University, while the field experiment was located at nearby Partners Relief and Development Farm (N 18 56.83, E 99 1.41), both in the city of Chiang Mai. For the uplands sites, both the greenhouse study and field experiment were located at the ECHO Asia Seedbank farm (N 19 58.33, E 99 19.43) near the town of Mai Ai. The first experiment was conducted in a greenhouse setting while the second was conducted in a field setting. The greenhouse experiment and the field experiment both utilized a Randomized Complete Block Design (RCBD) with eight replications.

\subsubsection{Greenhouse Study Experimental Design}

The greenhouse experiment was run on two separate occasions, once during the rainy season (run 1) and again during the dry season (run 2). Six independent treatments were included (Table 1) in the greenhouse experiment and blocked across the greenhouse gradient to account for shading effects; eight blocks were established in all.

Table 1. Summary of Treatments for the Greenhouse Experiment

\begin{tabular}{|c|c|}
\hline \multicolumn{2}{|c|}{ Greenhouse Experiment } \\
\hline Treatments & Treatment Description \\
\hline 1. Cont. & Control \\
\hline PIF & Stem Fragment Method \\
\hline BA1 & Benzyl aminopurine (BA) Drench $-{ }^{1}$ Concentrated \\
\hline BA2 & Benzyl aminopurine (BA) Drench $-{ }^{2}$ Half Concentration \\
\hline 5. $\mathrm{CW}$ & Coconut Water Drench \\
\hline 6. $\mathrm{SC}$ & Split Corm Method \\
\hline
\end{tabular}

${ }^{1} 10^{-2} \mathrm{M}$ of Benzyl aminopurine

${ }^{2} 5 \times 10^{-3} \mathrm{M}$ of Benzyl aminopurine

Detailed descriptions of each of the treatments is listed below:

(1) Control - the corm's cortex (including the roots) was peeled away and the pseudostem removed just above the transition zone. Corms were dried overnight before being placed in a moist rice husk bed. (2) Stem Fragment Method - the corm's cortex (including the roots) was peeled away and the pseudostem cut off one sheath at a time, along the transition zone until the edges of the leaf sheath overlapped. The central apex of the pseudostem was cut $2 \mathrm{~cm}$ above the last cut. After allowing corms to dry two days (in order to induce stress), the central apex was cut back little by little, until the tip of the apical meristem could be clearly discerned. The meristem was then damaged with three crosswise cuts through the central point and allowed to dry for several hours before planting. (3) BA Drench 1 (Concentrated) - corms were dipped into a concentration of $10^{-2} \mathrm{M}$ BA for 30 minutes, and apical meristems were subsequently bored out. The corms were then allowed to dry overnight before being placed in a moist rice husk bed. In preliminary studies, $4 \mathrm{~mL}$ of BA was injected into the base of split-corm derived suckers (as per Osei, 2005), but because of the difficulty of injecting liquid into the banana corm, a drench was used instead. (4) BA Drench 2 (Half Concentration) - corms were treated identically to those treated with BA Drench 1 but half the concentration was used $\left(5 \times 10^{-3} \mathrm{M}\right)$. (5) Coconut Water Drench - corms were submerged for 30 minutes in fresh, strained coconut water from mature green coconuts (obtained at a local Chiang Mai market) after having the apical meristems bored out. The corms were then allowed to dry overnight before being placed in a moist rice husk bed. (6) Split Corm Method - pseudostems and roots were removed, leaving only the peeled corm. This was cut into quarters, and dried overnight before being placed in a moist rice husk bed.

\subsubsection{Field Study Experimental Design}

The field experiment included a separate set of macropropagation techniques better-suited for in situ propagation of banana plants. This included five separate independent treatments (Table 2), and treatments were blocked according to shading gradient, for a total of eight blocks. 
Table 2. Summary of Treatments for the Field Experiment

\begin{tabular}{lll}
\hline \multicolumn{3}{l}{ Field Experiment } \\
\hline \multicolumn{2}{l}{ Treatments } & Treatment Description \\
1. & Cont. & Control \\
2. & MM & Mother Plants Bent and Staked \\
3. & BA1 & Benzyl aminopurine (BA) Pooled $-{ }^{1}$ Concentrated \\
4. & BA2 & Benzyl aminopurine (BA) Pooled $-{ }^{2}$ Half Concentration \\
5. & CW & Coconut Water Pooled in Sword Suckers \\
\hline
\end{tabular}

${ }^{1} 10^{-2} \mathrm{M}$ of Benzyl aminopurine

${ }^{2} 5 \times 10^{-3} \mathrm{M}$ of Benzyl aminopurine

Detailed descriptions of each of the treatments is listed below:

(1) Control - banana mats were observed under natural growing conditions, without any manipulation to the plant. (2) Mother plants bent and staked - young mother plants were bent over at the top, at a height of $2 \mathrm{~m}$, then a thin, flat bamboo stake ( $5 \mathrm{~cm}$ wide) was driven into the center of the pseudostem at a height of $15 \mathrm{~cm}$, with the intention of killing the apical meristem. (3) BA Pooled 1 (Concentrated) - all sword suckers under one meter were exposed at the base of the mother plant. The pseudostems were removed $2 \mathrm{~cm}$ above the rhizome collar and the apical meristem bored out. The remaining fragment was then cut with crosswise incisions, cutting down to the transition zone, and the hole filled with $4 \mathrm{~mL} \mathrm{BA}\left(10^{-2} \mathrm{M}\right.$ concentration). The depressions were then covered with enough of a mixture of soil, rice husks and manure to cover the corms completely, before filling the rest of the depressions in with topsoil. (4) BA Pooled 2 (Half Concentration) - corms were treated identically to those treated above but half the concentration of BA was used $\left(5 \times 10^{-3} \mathrm{M}\right)$. (5) Coconut Water Pooled - all sword suckers less than one meter were exposed at the base of the mother plant. The pseudostems were removed $2 \mathrm{~cm}$ above the rhizome collar and the apical meristem bored out. The remaining fragment was then cut with crosswise incisions, cutting down to the transition zone, and the hole filled with $4 \mathrm{~mL}$ coconut water from mature, green coconuts. The rhizomes were then covered with a mixture of soil, rice husks and manure.

\subsubsection{Greenhouse Corm and Planting Bed Preparation}

Musa (ABB) cv. 'Kluai nam wa' sword suckers $(<100 \mathrm{~cm}$ height) were used for greenhouse trials, and were collected from local small-scale farms. In all greenhouse trials, sword suckers, less than one meter tall, were dug five days before re-planting. Replications were laid out to have similar sized corms distributed throughout blocks and randomly assigned to treatments.

For all corms, the corm cortex was peeled away with a sanitized knife in order to cut away any potential pest, nematode or disease damage present and the pseudostem was removed, one leaf sheath at a time, just above the transition zone until edges of the leaf sheaths fully overlapped. Leaf sheaths were removed individually in order to keep from damaging the apical meristem. Treatments were then applied as described above.

Planting beds were prepared 1-2 weeks prior to corm treatment. Due to its wide availability in developing world tropics, rice hulls were selected as the growing media. The rice hulls were purchased locally and treated with the fungicide, pentachloronitrobenzene, by diluting $60 \mathrm{~mL}$ in $20 \mathrm{~L}$ of water and evenly pouring the solution over the bed two days prior to planting. The treated corms were positioned randomly, $3-6 \mathrm{~cm}$ apart in each of eight replicated blocks at each site. Prior to treating, different sized corms were applied to each replication to normalize corm size across treatments, in order to make all replications have consistently sized corms. Once the corms were positioned, the beds were covered with clear plastic to simulate greenhouse conditions and covered with 50\% shade cloth to protect the new leaves from sunburn. Watering occurred weekly, supplying enough water to fully saturate the rice hulls. This kept the bed moist throughout the week, as rice hulls have a high water holding capacity. Each experiment at each site was repeated for three months in the rainy season and three months in the dry season. These repeats were a proxy for the rainy and dry seasons as the experiments actually started late in the seasons.

\subsubsection{Field Banana Sucker Preparation}

Musa $(\mathrm{ABB}) \mathrm{cv}$. 'Kluai nam wa' sword suckers $(<100 \mathrm{~cm})$ were also used for field trials. In both field trials, sword suckers, less than one meter in height, were used. Because of the way the farms were set up, banana plants were not all planted at the same time and it was difficult to find 40 mats of the same age. Thus, each block was chosen to have banana mats close to the same age and in similar environmental gradients. For the treatments of 
Control, BA1, BA2, and CW, plant mats were selected that had no more than three mother stalks and no more than seven suckers per mat. In contrast, for the MM treatment, younger mats were selected, with only one or two mother stalks and no more than one sucker. Replication plant groups were selected and then treatments were randomized and assigned within each replication.

\subsection{Data Collection and Analysis}

Dependent variable data collection took place on a weekly basis, and included the date of plantlet emergence, number of emerged plantlets per corm, and height and circumference of plantlet and sucker pseudostems. Height was measured from the transition zone (where outer leaf sheath meets corm) to the top of the pseudostem, the base of the youngest leaf. Circumference was measured at the soil or greenhouse substrate surface. Emergence was measured as the date the plant pushed through soil/substrate surface. The number of plantlets was evaluated as the number to survive until the end of 90 days for the greenhouse experiments and 120 days for the field experiments.

Greenhouse temperatures were recorded every two hours using a HOBO® Data Logger (1996) in each location. Ambient temperature was obtained from local weather stations in Chiang Mai (Wunderground, 2012a) and Chiang Rai (Wunderground, 2012b).

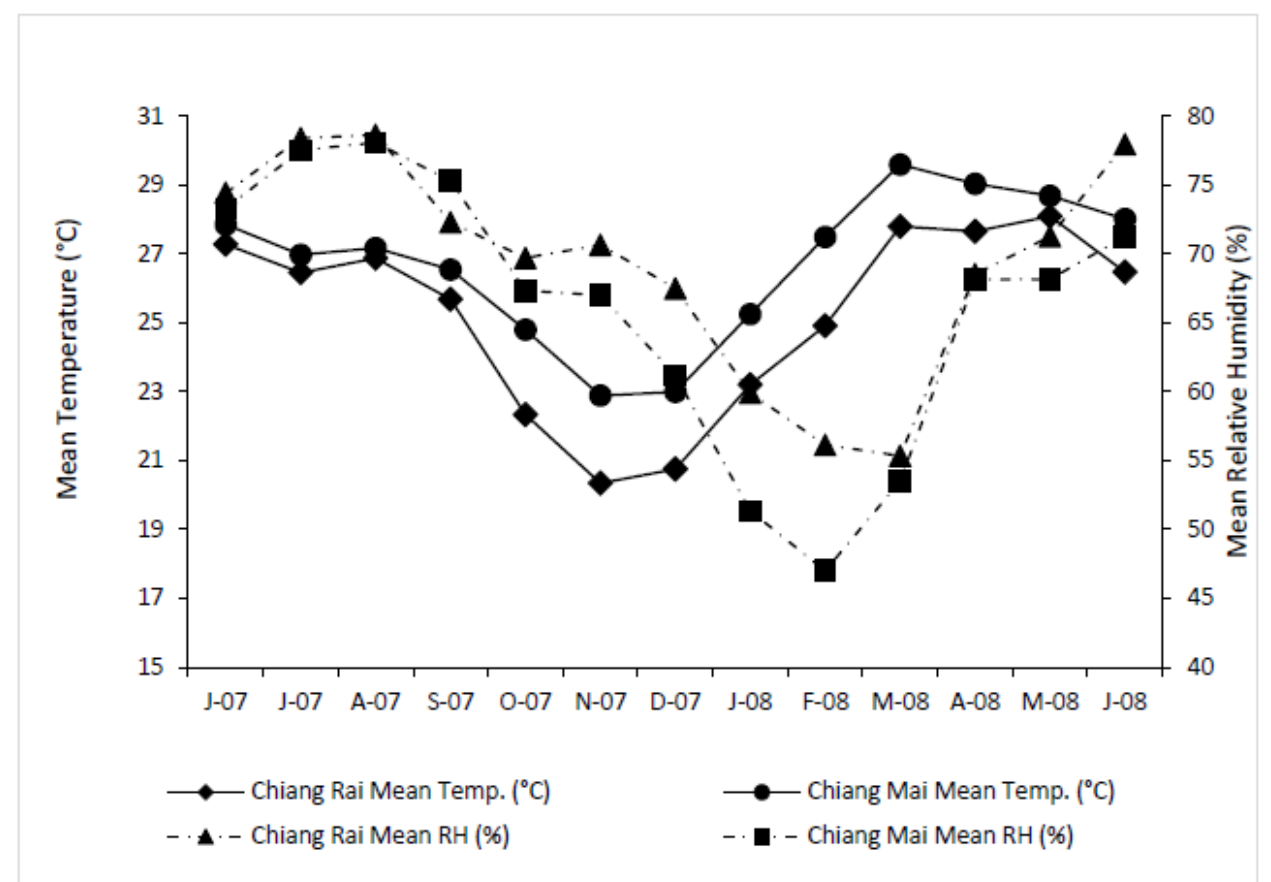

Figure 1. Mean Temperature $\left({ }^{\circ} \mathrm{C}\right)$ and Mean Relative Humidity $(\mathrm{RH})$ in Chiang Rai (Uplands site) and Chiang Mai (Lowlands site) between June 2011 and June 2012 (Wunderground, 2012ab)

Data for the greenhouse and field experiments were analyzed separately as linear mixed models using the MIXED Procedure of SAS (SAS Institute, Inc, Cary, NC). Site, repeats (greenhouse only- analyzed as a fixed effect to parse out its potential for influencing treatments based upon clear climatic fluctuations over the experimental period), and treatments were considered fixed effects. It should be noted that in regards to the control treatment, emerging plantlets cannot strictly be considered plantlets in the same sense, as they were not derived from lateral buds, but rather from the meristem.

\section{Results}

\subsection{Greenhouse Experiment Results}

\subsubsection{Temperature and Relative Humidity}

Climate and seasonality appear to have made more of an impact of plantlet emergence than site location in this experiment (Table 3). Significant differences $(\mathrm{p}<0.001)$ were detected between runs (experiment timing) for number of plantlets to emerge and number of days to emergence, and only circumference of plantlets was significantly different $(\mathrm{p}<0.001)$ between sites. Temperature decreased as the season changed from rainy season to dry season with slightly higher temperatures in the lowlands than in the uplands (Figure 1). Measured 
greenhouse low temperatures were very close to ambient lows and included some periods of time, especially during the evenings, below the base growing point for bananas of $14^{\circ} \mathrm{C}$. High temperatures were also often above the optimal temperature for banana plantlet growth at $37^{\circ} \mathrm{C}$ (Robinson, 2010).

\subsubsection{Number of Emerged Plantlets}

While the rainy season (run 1) produced a significantly $(\mathrm{P}<0.05)$ greater number of plantlets than during the dry season (run 2) at both sites, there was not a significant difference in the numbers of plantlets produced between the uplands and lowlands sites (Figure 2).

Table 3. Analysis of variance for main effects and interactions of site, run, treatment, and block.

\begin{tabular}{lcccc}
\hline Source & df & $\begin{array}{c}\text { Number of Emerged } \\
\text { Plantlets }\end{array}$ & $\begin{array}{c}\text { Days to Emergence } \\
\text { Site }\end{array}$ & $\begin{array}{c}\text { Circumference of } \\
\text { Plantlets (cm) }\end{array}$ \\
Run & 1 & $\mathrm{~ns}$ & $\mathrm{~ns}$ & $* * *$ \\
Treatment & 5 & $\mathrm{~ns}$ & $\mathrm{~ns}$ & $\mathrm{~ns}$ \\
Site x Run & 1 & $*$ & $*$ & $*$ \\
Site x Treatment & 5 & $\mathrm{~ns}$ & $\mathrm{~ns}$ & $\mathrm{~ns}$ \\
Run x Treatment & 5 & $*$ & $*$ & $\mathrm{~ns}$ \\
Site x Run x Treatment & 5 & $\mathrm{~ns}$ & $\mathrm{~ns}$ & $\mathrm{~ns}$ \\
Block(Site, Run) & 4 & $\mathrm{~ns}$ & & $\mathrm{~ns}$ \\
\hline Model & 27 & & & $\mathrm{~ns}$ \\
Error & 164 & & & \\
Total & 191 & & & \\
\hline
\end{tabular}

* - Significant at $\mathrm{p}<0.05, * * *$ - Significant at $\mathrm{p}<0.001, \mathrm{~ns}-$ not significant

With regard to the effect of treatment in the rainy season, BA1 produced significantly $(\mathrm{P}<0.05)$ more plantlets than PIF, while in the dry season there was not a significant difference by treatment. Although BA1 produced the greatest number of emerged plantlets in the rainy season, it produced the least number of emerged plantlets in the dry season across sites (Table 4). However, plantlets were still emerging at the end of the experiment, so it remains unknown as to whether the total number of plantlets would have increased further had the experiment been allowed to run for a greater length of time. Overall, there were not encouraging results from any of these treatments in terms of number of plantlets produced.

Table 4. Means comparison of the number of emerged plantlets between treatments by run across sites.

\begin{tabular}{clcc}
\hline Run & Treatment $^{1}$ & Least Squared Means $^{2}$ & Standard Error \\
\hline & BA1 & $1.56 \mathrm{a}$ & 0.25 \\
& SC & $1.13 \mathrm{ab}$ & 0.25 \\
1 & BA2 & $0.94 \mathrm{ab}$ & 0.25 \\
(Rainy Season) $)$ & Control & $0.75 \mathrm{~b}$ & 0.25 \\
& CW & $0.75 \mathrm{~b}$ & 0.25 \\
& PIF & $0.69 \mathrm{~b}$ & 0.25 \\
& & & \\
& Control & $0.63 \mathrm{a}$ & 0.15 \\
2 & SC & $0.63 \mathrm{a}$ & 0.15 \\
(Dry Season) & BA2 & $0.44 \mathrm{ab}$ & 0.15 \\
& CW & $0.38 \mathrm{ab}$ & 0.15 \\
& PIF & $0.19 \mathrm{~b}$ & 0.15 \\
& BA1 & $0.06 \mathrm{~b}$ & 0.15 \\
\hline
\end{tabular}

${ }^{1}$ Treatments: control (Cont), plants produced from stem fragments (PIF), benzylaminopurine $10^{-2} \mathrm{M}$ (BA1), coconut water (CW), split-corm (SC), and benzylaminopurine $5 \times 10^{-3} \mathrm{M}(\mathrm{BA} 2) .{ }^{2}$ Treatments with the same letter are not significantly different according to Fisher's protected LSD $(\alpha=0.05)$

\subsubsection{Days to Plantlet Emergence}

In the greenhouse experiment, there was not a significant difference in time to plantlet emergence between the uplands and lowlands sites, with an average of 50.79 days, but the timing of the runs created significant 
differences. In the lowlands, plantlets in the rainy season emerged earlier than in the dry season, but not significantly. However, for the uplands, plantlets in the rainy season emerged significantly $(\mathrm{P}<0.05)$ earlier than in the dry season. Across sites, plantlets in the rainy season emerged significantly $(\mathrm{P}<0.05)$ earlier than in the dry season (Figure 2). There were not significant differences between treatments for the dependent variable of time to plantlet emergence, although plantlets from all treated corms emerged later than the control during the rainy season and during the dry season. As with the number of emerged plantlets, lower temperatures in the dry season, especially in the uplands where temperatures are lower, may cause plantlets to emerge later.

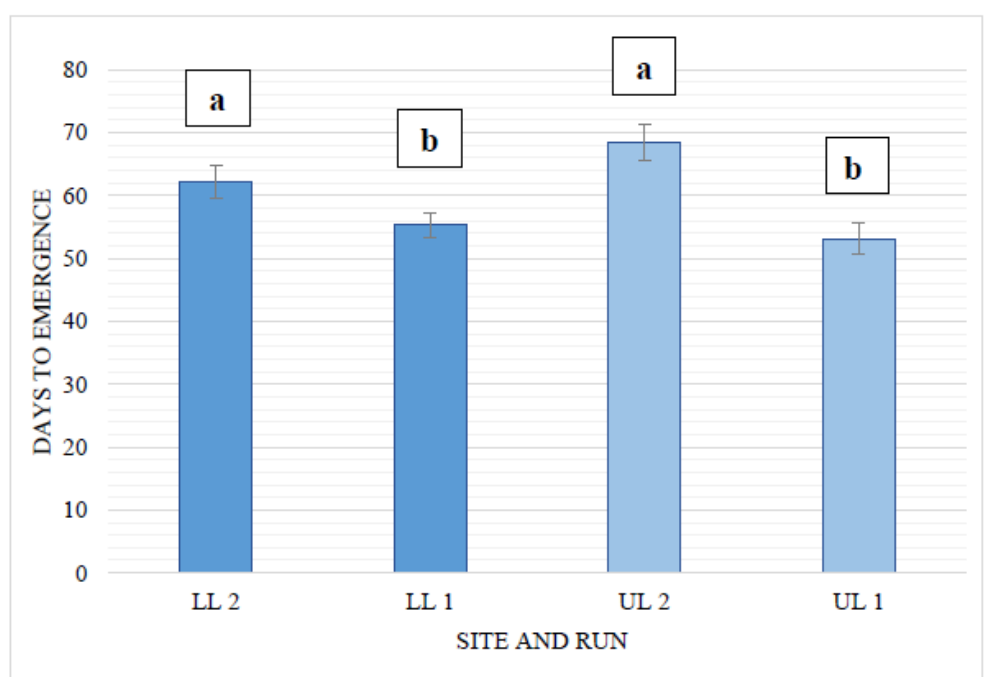

Figure 2. Number of days to emergence of plantlets at the Lowland (LL) and Uplands (UL) sites during the rainy season (1) and dry season (2) runs. Treatment runs with the same letter within site are not significantly different according to Fisher's protected LSD $(\alpha=0.05)$ and error bars represent one standard error of the mean

\subsubsection{Circumference of Emerged Plantlets}

In the greenhouse experiment, differences were not significant when running circumference as a function of site and run, although there was a slightly higher mean circumference across treatments in the lowlands and in the rainy season (LL1 > LL2 and UL1 > UL2). Between treatments, when averaged across sites and runs, there was not a significant difference in circumference with $\mathrm{BA} 1>\mathrm{BA} 2>\mathrm{CW}>\mathrm{PIF}>\mathrm{SC}$, with the exception of SC which had a significantly $(\mathrm{P}<0.05)$ lower mean circumference than BA1, BA2, CW and PIF (Figure 3). The SC treatment produced smaller corm circumferences than the other treatments, which was likely the result of the splitting of the corm into four sections.

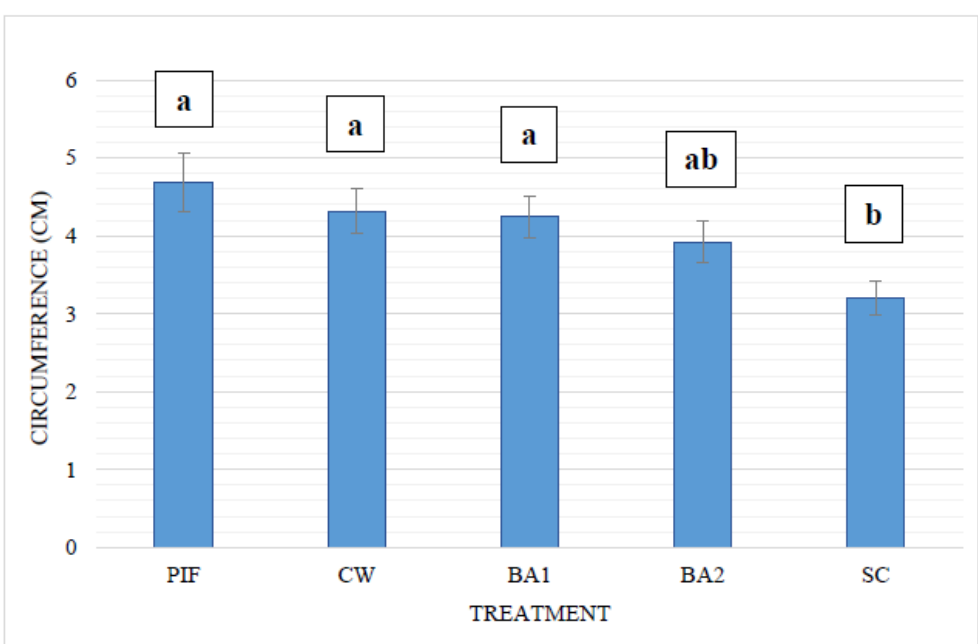

Figure 3. Circumference of emerged plantlets $(\mathrm{cm})$ as a function of treatments across all sites and runs. Means are the average of runs 1 and 2, as there were no significant differences between runs. Plants produced from stem fragments (PIF), coconut water (CW), benzylaminopurine $10^{-2} \mathrm{M}$ (BA1), benzylaminopurine $5 \times 10^{-3} \mathrm{M}(\mathrm{BA} 2)$, and 
split-corm (SC). Treatments with the same letter are not significantly different according to Fisher's protected LSD $(\alpha=0.05)$ and error bars represent one standard error of the mean

\subsection{Field Experiment}

In the field experiments, no significant differences occurred between uplands and lowlands or between treatments for the dependent variable of ratio of emerged plantlets to the number of treated plantlets, although numerically all treatments resulted in higher ratios than the control (Figure 4).

In the field experiment, plantlets in the uplands emerged slightly earlier than those in the lowlands, but not significantly. Treatments influenced the dependent variable of emergence in the order of: Cont > BA1 > BA2 > $\mathrm{CW}>\mathrm{MM}$, but again, there were no significant differences. Ambient temperatures at both upland and lowland sites were likely not extreme enough to affect the growth of the plantlets because temperatures stayed within the optimal range (Singh et al., 2011).

In field experiments, no significant differences occurred between sites, but there were significant differences between treatments. Plantlets in the uplands had a greater mean final circumference than in the lowlands, but not significantly. Across sites, $\mathrm{MM}$ treatment had a significantly $(\mathrm{P}<0.05)$ greater circumference than other treatments with the exception of $\mathrm{CW}$.

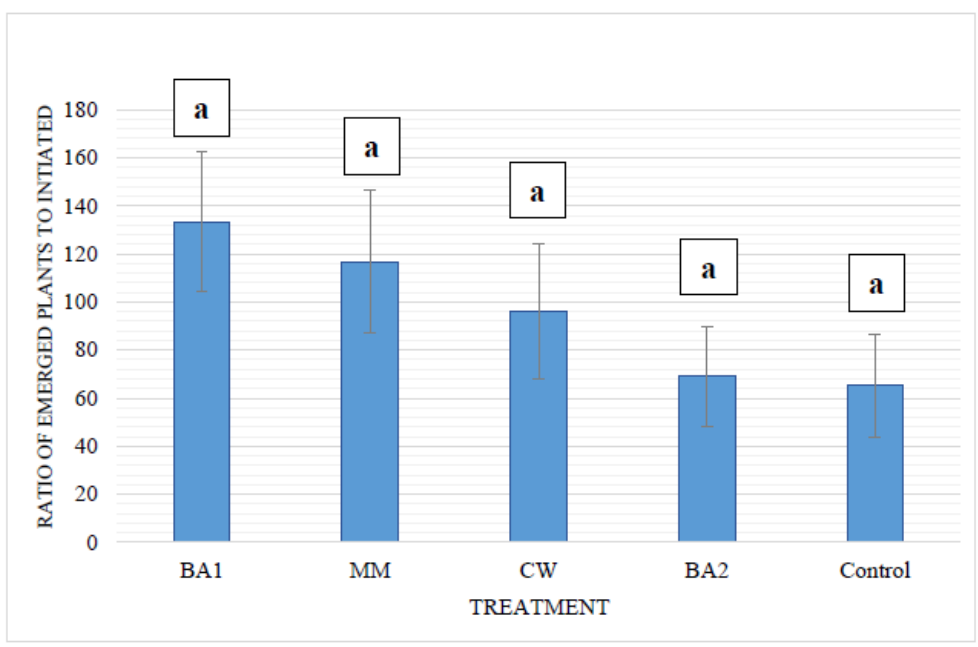

Figure 4. The ratio of the number of emerged plants to those initiated as a function of treatment across sites in the field experiment. Benzyl Aminopurine pooled (BA1), Mother plants bent and staked (MM), Coconut water pooled in sword suckers (CW), Benzyl Aminopurine pooled - half concentration (BA2), and Control (Cont.). Treatments with the same letter are not significantly different according to Fisher's protected LSD $(\alpha=0.05)$ and error bars represent one standard error of the mean

\section{Discussion}

Since temperature plays an important role in the growth of bananas, with $22-31^{\circ} \mathrm{C}$ being the ideal temperatures for optimal growth in bananas (Robinson \& Saúco, 2010), it is likely that temperature was a key factor influencing the number of plantlets produced between sites and runs.

As far as finding a superior macropropagation technique, this study is unable to conclude that any one of the treatments used was greater overall. Although the PIF treatment destroyed the apical meristem, reducing auxin production, and thus apical dominance (Boss, 2008), it did not affect levels of cytokinins, which are responsible for axillary growth induction, thereby providing a possible explanation of why the BA1 treatment produced more plantlets than the PIF treatment. Because of the lower temperatures in the dry season, plantlet emergence was delayed and perhaps different results would have emerged if we had run the experiment for a longer duration.

The numbers of plantlets produced from treated corms were significantly lower than the numbers found in the literature (Boss, 2008; Osei, 2004; Dzomeku, Banful, Ankoma, Yeboah, \& Darkey, 2000). A possible reason is that these studies regenerated plantlets to multiple generations, adding up the cumulative number of plantlets possible. Our study only used one generation of plantlets. Preece (2008) mentions, "shoot explants from juvenile plants generally proliferate more axillary shoots than shoot explants from adult forms" (Preece, 2008). Perhaps treating the plantlets produced from our treatments would produce increased numbers of plantlets. 
Another possible reason for lower numbers of plantlets than expected from the literature could be a result of the cultivar or species used in the experiments. In many of the prior experiments in the literature, the work was undertaken in Africa or Central America, and often used plantains as the subject plants. When working with tissue culture, cultivar has an impact on how many axillary buds develop, with diploids producing more buds than most commercial cultivars, which are typically triploids (Singh et al., 2011). In order to better understand the role the 'Kluai nam wa' cultivar played in numbers of plantlets produced, a study comparing different cultivars would need to be undertaken.

In the field experiment it is likely that the apical dominance of the older mother stalks had too much influence over the mats, preventing treated suckers from producing lateral bud formation. Because of apical dominance, a mat will only produce 5-20 suckers in a stalk's lifetime of 12-14 months (Singh et al., 2011). Research suggests that in addition to the apical dominance exerted by mother plants over suckers, suckers of the same mat also exert dominance over axillary buds and slow their growth (Pillay \& Tripathi, 2008). Both Macias (2001) and Rowe (Price, 1999) experimented with young mother plants with fewer mother stalks. The age of banana mother plants in our research was restricted to older plants because it was difficult to find fields with enough homogeneous young mats with few, small suckers. The number of plantlets produced from treated corms was significantly lower in both of our greenhouse and field experiments than the number reported from several individual studies (Boss, 2008; Osei, 2005; Dzomeku, Banful, Ankoma, Yeboah, \& Darkey, 2000; and Macias, 2001). It should be noted that attempts to inject coconut water or BA into the base of sword suckers as practiced by Osei (2005) was found to be difficult and impractical, hence holes were bored out and pooled in our study.

It is possible that MM treatments increased plantlet circumference because the inherent mat age of mother plants used for this treatment were younger than mats for other treatments. Older mats produce more water suckers, and water suckers have a smaller pseudostem circumference than sword suckers (Robinson \& Saúco, 2010), leading to weaker plants. Also, when damaged, corms tend to produce broader-leafed suckers, and may induce reduced plantlet circumference (Simmonds, 1966). It is possible that in the MM treatment, mother plants were young and suckers were not damaged, thereby producing suckers with larger circumferences. Conversely, Control, BA1, BA2, and CW treatments utilized older mats, perhaps producing more water suckers. Additionally, for these treatments, the corms were damaged (with the exception of Control), thereby encouraging plantlets with water sucker traits to emerge.

\section{Conclusion}

The objectives of this research were to determine the most effective macropropagation methods of Musa (ABB) cv. 'Kluai nam wa' in Northern Thailand, and the influence that time of year and location play on the growth of banana plantlets in order to find low-cost propagation techniques that resource-constrained farmers could use to propagate bananas to grow for pig fodder. Although the results were not as were expected, we think these results are an important contribution to the current literature on the subject. These results suggest that temperature and time of year may play a crucial role in the macropropagation of bananas, and that further research is needed to explore the viability of these various techniques and others. While the overall number of plantlets produced from these techniques were few in number, it is not safe to say that these techniques are meritless in the region, but rather need to be attempted under different conditions and for great lengths of time or on different cultivars.

\section{Acknowledgements}

This research was made possible in part by Fiat Panis and Chiang Mai University. We would like to thank our colleagues Dr. Daruni Naphrom, Dr. Jens Wünsche, and Dr. Choochad Santasup from Chiang Mai University and Hohenheim University, who provided insight and expertise that greatly assisted in this research. We would also like to show our gratitude to the staff at the ECHO Asia Seedbank and the Partners Relief \& Development Farm for your assistance.

\section{References}

Arinaitwe, G., Rubaihayo, P. R., \& Magambo, J. S. (1999). Effects of auxin/cytokinin combinations on shoot proliferation in banana cultivars. African Crop Science Journal, 7(4), 605-611. https://doi.org/10.4314/acsj.v7i4.27755

Boss, D. (2008). Rapid multiplication of banana and plantain plants. ECHO Development Notes, 99, 1-5.

Dzomeku, B. M., Banful, B., Ankoma, A. A., Yeboah, D. K., \& Darkey, S. K. (2000). Multilocational evaluation of FHIA hybrids in Ghana. INFOMUSA, 9(1), 20-22.

Ge, L., Yong, J. W. H., Tana, S. N., Yang, X. H., \& Ong, E. S. (2004). Analysis of some cytokinins in coconut (Cocos nucifera L.) water by micellar electrokinetic capillary chromatography after solid-phase extraction. 
Journal of Chromatography A, 1048(1), 119-126. https://doi.org/10.1016/S0021-9673(04)01186-0

Jafari, N., Othman, R. Y., \& Khalid, N. (2011). Effect of benzyl aminopurine (BAP) pulsing on in vitro shoot multiplication of Musa acuminata (banana) cv. Berangan. African Journal of Biotechnology, 10(13), 2446-2450.

Marcias, D. M. (2001). In situ mass propagation of the FHIA-20 banana hybrid using benzylaminopurine. INFOMUSA, 10, 3-4.

Njukwe, J., Ouma, E., van Asten, P., Muchunguzi, P., \& Amah, D. (2013). Challenges and Opportunities for Macropropagation Technology for Musa spp. among Smallholder Farmers and Small-and Medium-scale Enterprises. In G. Blomme, P. van Asten \& B. Vanlauwe (Eds.), Banana Systems in the Humid Highlands of Sub-Saharan Africa (pp. 66-71). Oxfordshire, UK: CAB International. https://doi.org/10.1079/9781780642314.0066

Osei, J. K. (2004). Rapid field multiplication of plantains using benzyl adenine or coconut water-treated split corms. Paper presented at the In Musa Network for West and Central Africa (MUSACO): Report of the fourth Steering Committee meeting held in Eat Legon, Accra, Ghana.

Pillay, M., \& Tripathi, L. (2008). Banana Breeding Breeding Major Food Staples (pp. 393-428): Blackwell Publishing Ltd. https://doi.org/10.1002/9780470376447.ch13

Preece, J. (2008). Stock plant physiological factors affecting growth and morphogenesis. In E. F. George, M. A. Hall \& G. J. De Klerk (Eds.), Plant Propagation by Tissue Culture (Vol. 1: The Background, pp. 403-422). The Netherlands: Springer.

Price, M. (1999). Rapid multiplication of banana plants in the field. ECHO Development Notes, 66, 2-3.

Robinson, J. C., \& Saúco, V. G. (2010). Bananas and Plantains Crop production science in horticulture. (2nd ed.). UK: CABI Publishing. https://doi.org/10.1079/9781845936587.0000

Simmonds, N. W. (1966). Bananas (2nd ed.). London, UK: Longman.

Singh, H. P., Uma, S., Selvarajan, R., \& Karihaloo, J. L. (2011). Micropropagation for production of quality banana planting material in Asia-Pacific. Paper presented at the Asia-Pacific Consortium on Agricultural Biotechnology (APCoAB), New Delhi, India.

Wareing, P. F., \& Phillips, I. D. J. (1970). Growth \& Differentiation in Plants, Third Edition. Oxford, UK: Pergamon.

Wunderground. (2012a). History for Chiang Mai International, Thailand. Retrieved from http://www.wunderground.com/history/airport/VTCC

Wunderground. (2012b). History for Chiang Rai International, Thailand. Retrieved from http://www.wunderground.com/history/airport/VTCT

Yong, J. W. H., Ge, L., Ng, Y. F., \& Tana, S. N. (2009). The chemical composition and biological properties of coconut (Cocos ucifera L.) water. Molecules, 14, 5144-5164. https://doi.org/10.3390/molecules 14125144

\section{Copyrights}

Copyright for this article is retained by the author(s), with first publication rights granted to the journal.

This is an open-access article distributed under the terms and conditions of the Creative Commons Attribution license (http://creativecommons.org/licenses/by/3.0/). 